\title{
Papers
}

Explorations into Children's Literature

\section{'I am sorry it is not more, but it is all I could earn': Presbyterian Children, Christmas and Charity in Colonial New Zealand, c.1909-1945}

\section{Hugh Morrison}

In February 1884 the Presbyterian mission ship The Dayspring departed the southern New Zealand city of Dunedin, en route back to the New Hebrides [Vanuatu] via Sydney, after completing a tour of the colony's main centres. The Otago Daily Times reporter observed that in Dunedin the ship was visited by 'close on 14,000 persons - children and adults', with another ' 600 children' as visitors prior to its departure from nearby Port Chalmers. The children inspected 'various curios' in the cabins and at least saw, if not interacted with, five 'natives' on board. These four men and one woman, from the New Hebrides, had 'shown themselves to be possessed of much intelligence and observation' who, through 'missionary labour and Christian instruction', had been 'transformed from savage cannibals into peaceful, gentle Christians' ('The Dayspring' 1884, p. 2).

This article explores the relationship between British settler society children, Protestant missionary periodical literature, and charitable activity, focusing on the specific setting of the New Zealand Presbyterian Church between 1909 and 1945. By the last decades of the nineteenth century foreign missions and missionaries were well established in Protestant church life and identity across Europe, North America, Britain and its white settler colonies (Cox 2008; Robert 2009); children were important to this movement from its beginning. For 
New Zealand Protestant children, by the 1880 s, the main geographical focus was on the South West Pacific, although that focus would shift to South and East Asia by the early 1900s. Regular visits from mission ships like The Dayspring to the key port settlements of Auckland, Wellington and Dunedin connected colonial children physically and mentally with the South West Pacific in particular and missionary work more broadly. These ships were an exotic manifestation of a larger material, pedagogical and ideological culture that progressively imbricated colonial children within the missionary movement and wider definitions of Protestant Christianity.

This missionary culture was imported largely from Britain, but by 1900 had been established and adapted in settler society. Charitable activity and attitudes were key expressions of this culture. Beginning in the 1840 s British world children, ships and money were explicitly linked in a systematic effort to engage children's missionary support and enthusiasm (Elleray 2011). In the New Zealand colonial context, this came full circle in 1935 when a new Presbyterian boat built for the New Hebrides was named the Break of Day in honour of the many children in New Zealand who had supported missions over several decades ('The Break of Day' 1935, p. 3). Through the nineteenth century charity expanded to enlist children's support for targeted, achievable goals through campaigns and schemes that became ever more creative and context-specific. By the early 1900s these projects were both embedded within institutional Christianity and buttressed by children's literature and especially periodicals. This pertained across the Anglo-American Protestant and Roman Catholic spectrum. ${ }^{1}$ In New Zealand, from about 1870 onwards, settler children participated in an increasingly diverse and sophisticated range of charitable projects and actions directly

\footnotetext{
${ }^{1}$ For example: Harrison 2008; Hillel 2011; Mascarenhas, Gibson, \& Richard 2014; Miller 2012; Schoepflin 2005.
} 
linked to denominational missionary activity: examples included material projects (Indian house boat shares, sponsoring hospital beds), birthday clubs, photography and cooking competitions, tableaux and drama evenings, rallies, sales and concerts, making Christmas tree gifts, forming clubs, and general fundraising among many others (Morrison 2016, pp. 168171).

In this article I pose two questions: what sense do we make of settler Protestant children's charitable relationship to overseas missions?; and what is significant about how this was mediated through religious magazines? Children's mission-focused charity and pedagogy certainly can be interpreted in terms of financial gain, socialisation, transnational or imperial citizenship, the formation of racial attitudes, or within the wider context of women's charitable work and public religion. ${ }^{2}$ Two recent essays contribute to our understanding of that relationship and the nuances of particular geographical and religious contexts. First, in a thought-provoking essay on the French Holy Childhood Association - a European Roman Catholic children's missionary movement established in 1843 - Sophie Heywood notes the above historiographical emphases, but suggests that the 'importance of forging strong European links between members at home ... has therefore been overlooked' (2015, p. 448). While she emphasises 'political, social and cultural concerns' (2015, p. 448), Heywood discusses this with respect to the formation of 'a sense of community and solidarity' and therefore of shared transnational 'identity' among Catholic children within Europe (2015, p. 456). Second, Michelle Elleray suggests that missionary periodicals published from the 1840 s, and the charitable participation that they encouraged, constituted a 'broader cultural movement to provide morally appropriate texts for this age group' and reflected a distinctive

\footnotetext{
${ }^{2}$ See further: Hillel 2011; Jensz 2012, Morrison 2016; Prochaska 1978; Prochaska 1980; Vallgårda 2015.
} 
'cultural shift' in thinking about child readership and agency on the part of adult publishers and pedagogues (2011, pp. 231, 232).

These arguments resonate with the colonial New Zealand context, wherein it is possible to hypothesise that religious magazines and charitable activity together helped to form a sense of nationally 'imagined community’3 (Anderson 1991) among Protestant children that was marked by active participation and not merely passive reception. This article argues that the New Zealand Presbyterian children's missionary periodical The Break of Day mediated religious identity and missionary charitable activity and, in turn, contributed to the formation of colonial Protestant childhoods. ${ }^{4}$ Through a case study approach, this article focuses on one representative New Zealand denomination (Presbyterian - which constituted 25 per cent of the total population across this period), one pedagogical medium and archival space (the Break of Day magazine), and one charitable project (the annual Christmas present fund), emphasising both the mechanics of juvenile charity and its historical and historiographical significance.

\section{Origins and Evolution of The Break of Day}

In 1911 the New Zealand Presbyterian Foreign Missions Committee noted that it was 'indebted' to The Break of Day because the 'admirable letters of the editor to his young

\footnotetext{
${ }^{3}$ Here the term 'imagined community' is borrowed from Benedict Anderson's celebrated book of the same name, but in this current context it remains ambiguous in terms of how far that community was primarily thought of in religious/spiritual, denominational, national or transnational terms.

${ }^{4}$ Two points of definition are required here: (1) unless otherwise specified 'childhood' throughout this article refers in the main to children up to about the age of twelve or thirteen years of age; (2) and the children under scrutiny are predominantly 'settler' as opposed to Indigenous (that is Pākehā children of immigrant or European settler descent rather than Māori children). By 1900 colonial New Zealand childhoods and children's experiences were differentiated (although not exclusively) along these cultural / ethnic lines (May 2001).
} 
friends and of his contributors do much to awaken the interest of the schools in mission work' (FMC 1911, p. 43A). It noted that the 'youthful readers have sent a Christmas gift each year to one of our Mission Hospitals' (FMC 1911, p. 43A). Both the magazine and 'gift' concept were barely two years old at this point, but they had already made their mark in wider church life, reflecting the extent to which children and missions had become Presbyterian priorities by the early twentieth century. Furthermore, both magazine and 'gift' existed symbiotically, taking on an enduring life of their own.

The Break of Day appeared as the Presbyterian Church sought to consolidate both its national identity and overseas missions focus. Children were important to each. From 1866 the New Zealand Presbyterian Church was split geographically and theologically into two Churches until re-union in 1901 (McEldowney 1990). Out of this historical conjuncture arose the perceived need for a children's missionary 'paper', ${ }^{5}$ one that would foster 'an intelligent interest in mission work in heathen lands and in the Dominion' (YOCC 1908, p. 127). It was first published cheaply in February 1909 (see Figure 1), jointly supported by the Sunday Schools and Foreign Missions committees, and distributed through Sunday school channels. The rationale for the title was unclear, as was the choice of editor. Editorial energy and enthusiasm was a critical factor in its anticipated impact. An incumbent minister, the Rev. James Aitken, was chosen, possibly for his ability to communicate effectively with children (ODT, March 2, 1916, p. 6). Aitken was a Scottish Free Church minister committed to

\footnotetext{
${ }^{5}$ The following discussion, unless otherwise indicated, is based on the following sources: Sunday School Committee Minutes, 1907-1910; Foreign Mission Committee Minutes, 19081911; Foreign Mission Committee Reports to General Assembly, 1909-1913, Youth of the Church Reports to General Assembly, 1908-1914.
} 
community engagement who used his literary passions and expertise for the sake of his child readers. ${ }^{6}$

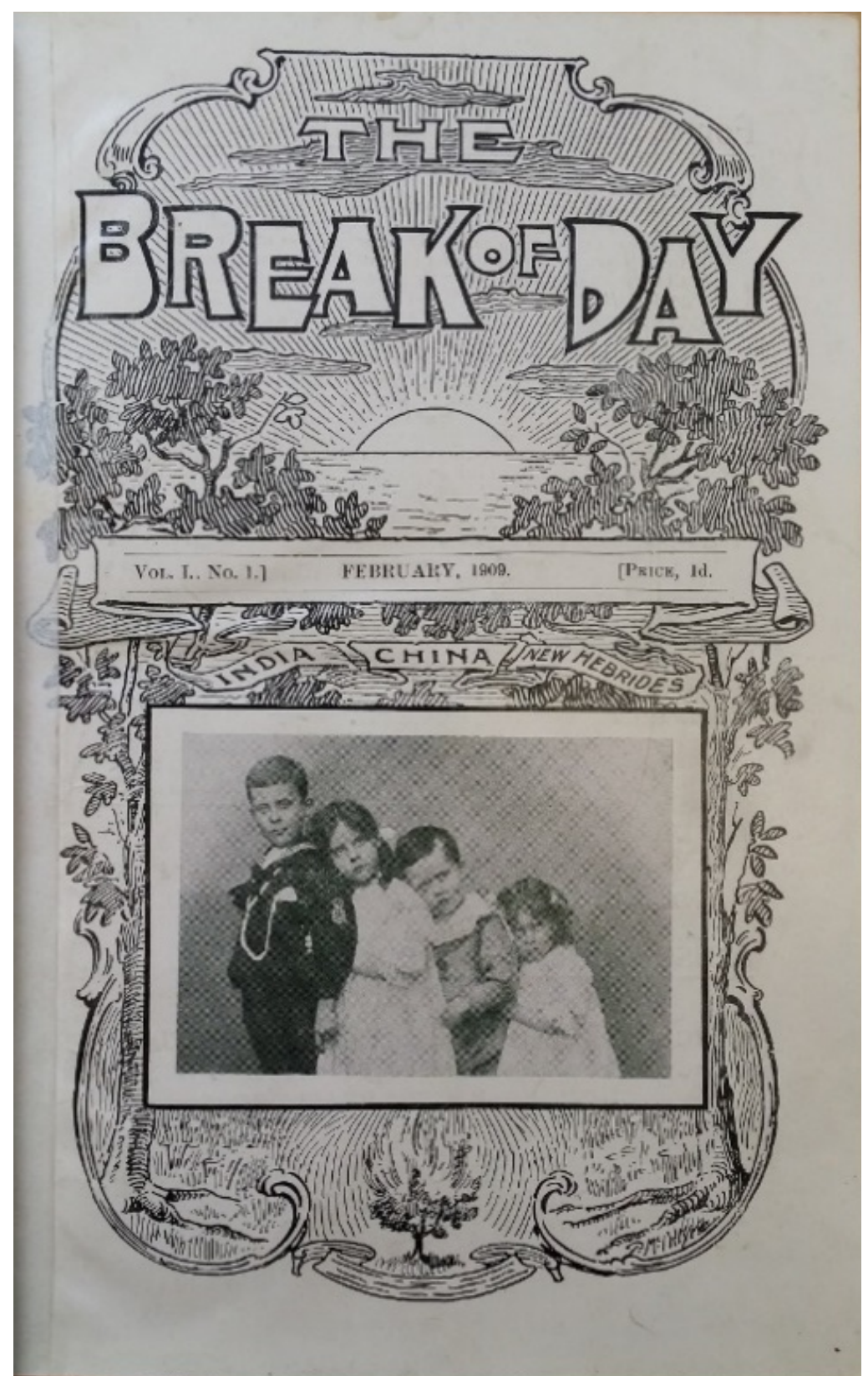

Figure 1: The Break of Day Magazine, first issue, February 1909 (Presbyterian Research Centre (Archives) - used with permission)

\footnotetext{
${ }^{6}$ James Aitken gave public lectures on literary topics, actively engaged in wartime charity, participated on school boards and was publicly involved in post-war public memorialisation projects.
} 
Alongside missionary activities, the magazine was intended to encourage children's interest in religious work. In the first issue the Rev. John McKenzie (Sunday schools Convenor) informed children that 'We are all very much interested in you' $(1909, \mathrm{p} .1)$. That interest was both genuine and pragmatic. Children were cast as 'good soldiers of Jesus Christ' who would 'carry on the work of the Church when we who are older are dead and gone' (McKenzie 1909, pp. 2-3). The magazine aimed to inform children generally and also to 'tell you about God's work in the world to-day' (McKenzie 1909, p. 3). In return children were charged with a responsibility:

Will you read carefully what we write? Will you think about our missionaries and the boys and girls at home and abroad who know nothing of the love of Jesus? Above all, will you choose Christ to be your Master, and resolve by His grace to work and pray for the extension of His kingdom in New Zealand and in the far lands across the sea [?] (McKenzie 1909, p. 3).

Personal engagement was Aitken's favoured strategy for showing and eliciting children's interest. He did this through relationship building and content selection, adopting a warm, familial approach to his role, an approach replicated by editors and publishers in other denominational or national contexts for the same period. ${ }^{7}$ He wanted to hear from children, via their letters. His readers responded and this correspondence became an enduring feature of the magazine. Children's personal engagement was further reinforced through the initiation of a 'Birthday Book' club that required children's annual registration; its membership grew to around 800 within three years ('Editorial' 1912, p. 2).

\footnotetext{
${ }^{7}$ Morrison 2015a; Morrison 2015b; Troughton 2017.
} 
The idea of a Christmas fundraising project arose directly from this strategy of engagement and quickly became the magazine's primary charitable focus. Project-specific charitable support for missions was well established in other colonial denominations, and the power of the spare penny was a successful strategy in missionary and other charitable literature (Hillel 2011, p. 182). Here, though, Aitken turned the prospect of charitable activity into a game. In August 1909 he offered a teaser by wishing readers a somewhat premature 'Happy Christmas' and by mysteriously suggesting that 'One way of making Christmas happy for somebody is to give a nice present. Now, I am going to ask you all to join me in giving a present [to celebrate the birthday of Jesus]' ('Editorial' August 1909, p. 1). Invoking Christ's message that 'Inasmuch as ye did it unto one of these my brethren, ye did it unto me' (Matt. 25: 40) - reiterated in editorials over the following months - he then suggested that children's support for a new Presbyterian hospital in Canton (Guangzhou) would ensure that 'The Chinese will have a happy Christmas' ('Editorial' August 1909, p. 2). Aitken left his readers hanging; children were simply told to 'get hold of a threepenny bit', 'put it by in a safe place', and 'watch for next month's' issue ('Editorial' August 1909, p. 2). The September issue laid out the details (Figure 2) encouraging children to save or collect their spare three penny bits. They could ask their parents, but a better option was to earn the money 'in all sorts of ways' ('Editorial' 1909, p. 2). As an incentive Aitken offered two prizes for the best letters describing their efforts and indicated that contributions would be listed in the following issues (p. 2 and back cover). The Ko T'ong Hospital fund was the focus for the rest of 1909 , with money and letters arriving regularly over those 


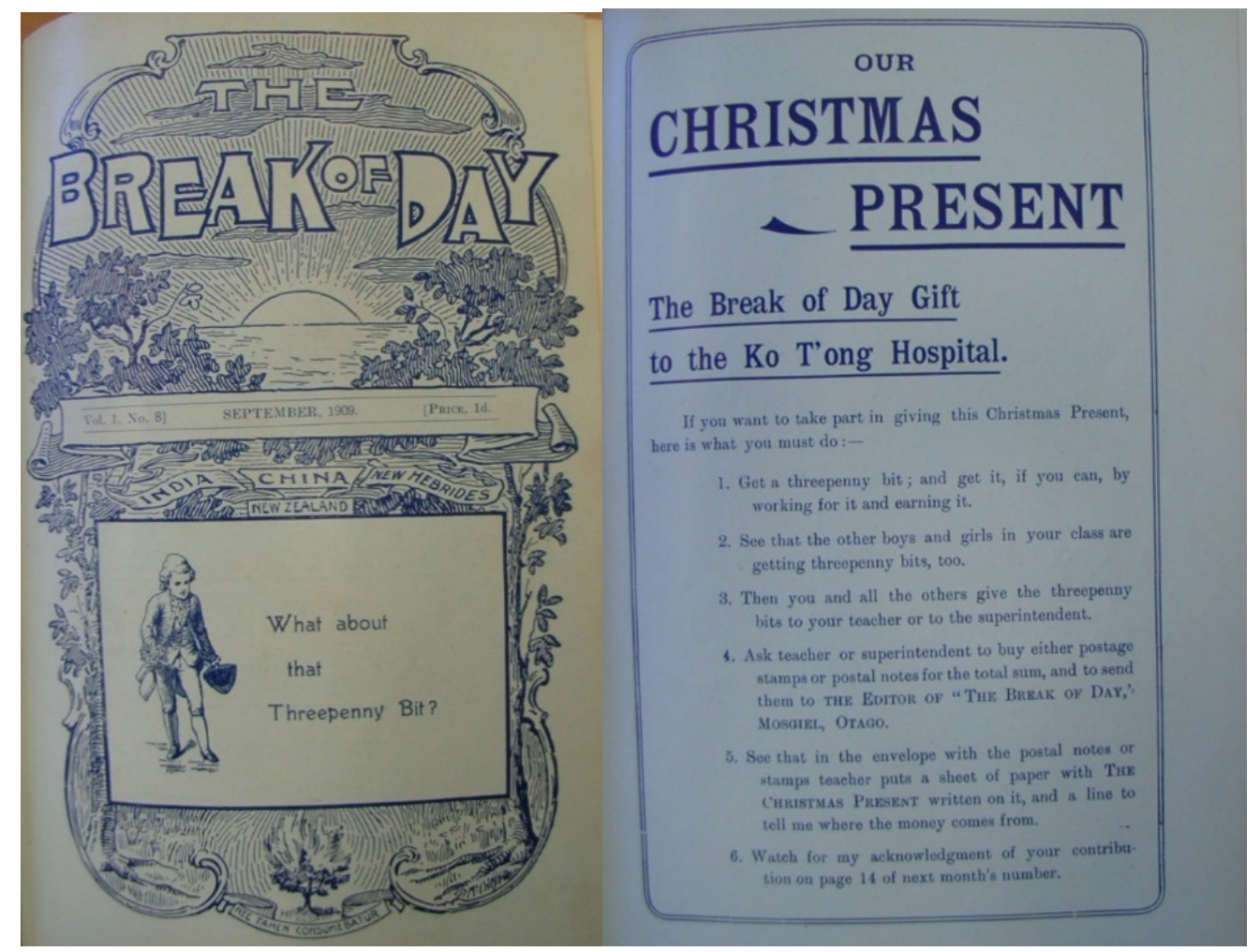

Figure 2: Advertising for the first Christmas Present Project (BoD, September 1909)

(Presbyterian Research Centre (Archives) - used with permission)

months. By November $£ 32$ 2s. 6d. had been sent to Aitken along with 167 letters ('Editorial' November 1909, pp. 1-2). Jane Reiher (aged 14) won the girl's prize and Jack Forsyth (aged 7) the boy's prize. Jane collected three different lots of money that were consequently given to other good causes (creating a park for old people in America and twice passing on the money to her mother to buy food for the family) before eventually earning the Christmas fund money by collecting wild flowers in the nearby countryside, getting wet and extremely muddy in the process. By way of contrast, Jack wrote:

I am sending you along one shilling .... . I am sorry it is not more, but it is all I could earn. I gathered one and a-half dozen medicine bottles and took them to Hokitika, three miles away, and sold them for ninepence; but I had to go back twice before I got 
paid for them. The other threepence I got from my aunt to pay for a ride home one of the times, but I walked and saved the money to send to you.

('Editorial' November 1909, p. 3).

It is worth speculating that Aitken reproduced these letters here to reinforce a message that a small amount of money raised through adversity was worth the effort, and that this was a task equally for boys and girls. Both children lived in smaller and somewhat remote rural centres in different parts of New Zealand's South Island. Perhaps, too, the children involved perceived that here was an opportunity to have their 'moment in the limelight' of national readership, given their relative isolation. The final sum collected and sent to China was $£ 36$; not a huge sum, perhaps, but one that Aitken felt pleased about. Dr John Kirk, the missionary in Canton, was also pleased. He wrote appreciatively:

My word, what a lot of little heroes and heroines New Zealand has! Tell them all how much I appreciate their gift. Many a little Chinese boy and girl, and many a grown up Chinese father and mother, are as grateful as I am.... I think that we can get an instrument case and an operating table as well. They shall be duly inscribed, with a little plate telling their story, not only in English, but in Chinese, so that every visitor and patient may know why they came and where they came from.

('Editorial' April 1910, p. 2)

A year later, in August 1910, Aitken explained his idea that the charitable giving from the previous year could be repeated:

[D]o you know an idea that has been cropping up in the minds of quite a lot of my young friends? .... It is the idea that it is rather good fun making Christmas presents. Ever so many boys and girls enjoyed working for the Ko T'ong present last year ... that they are anxious to get to work as soon as possible for a present for somebody this Christmas too. What do you think! It seems rather a good idea, does it not! 
('Editorial'August 1910, pp. 2-3)

Since Aitken was a playful editor, he may simply have been drawing children into longerterm engagement and support. His comment does suggest, however, that he initially conceived of the 'Christmas Present' idea as a one-off event and changed his mind in response to the children's enthusiasm. Either way, the idea endured, generating at least $£ 13,159$ between 1909 and 1945 for a host of projects set in a range of geographic locations (Table 1).

From 1910 the magazine fell into a regular pattern: each August or September a specific project was advertised, progress was communicated up to December, and in February or March the following year a total would be announced, sometimes followed by a letter of thanks from the fund's recipient(s). Children's initial interest was held and within seven years the annual total cleared the $£ 100$ barrier. Modest annual growth was sustained until 1936 , at which point the totals increased significantly over the next decade (Figure 3). What was remarkable, perhaps, was the sustained giving through both World War I - when children's fundraising energies were directed towards other patriotic priorities (Graham 2008) - and the Depression years (albeit with some fall off), and the demonstrable and sustained increases through the years of World War II. 
Table 1: Christmas Present Fund Projects and Contributions, 1909-1945

\begin{tabular}{|c|c|c|c|c|c|}
\hline Year / Project & Location & Amount & Year / Project & Location & Amount \\
\hline 1909 Ko T'ong hospital & South China & $£ 362 \mathrm{~s}$ & $\begin{array}{l}\text { 1928 Dispensary/hospital } \\
\text { at Te Teko }\end{array}$ & $\begin{array}{l}\text { Māori } \\
\text { Mission }\end{array}$ & $£ 278179$ \\
\hline 1910 Shahabad hospital bed & North India & $£ 45$ & $\begin{array}{l}1929 \text { Building mission } \\
\text { station on Ambrym }\end{array}$ & \begin{tabular}{|l|} 
New \\
Hebrides \\
\end{tabular} & $£ 31012$ \\
\hline $\begin{array}{l}1911 \text { Ambrym hospital } \\
\text { buildings }\end{array}$ & New Hebrides & $£ 6410 \mathrm{~s}$ & $\begin{array}{l}\text { 1930 Kong Chuen hospital } \\
\text { infrastructure and } \\
\text { maintenance }\end{array}$ & $\begin{array}{l}\text { South } \\
\text { China }\end{array}$ & $£ 428155$ \\
\hline $\begin{array}{l}1912 \text { NZ Presbyterian } \\
\text { orphanages }\end{array}$ & New Zealand & $£ 79$ & $\begin{array}{l}1931 \text { School for India } \\
\text { mission }\end{array}$ & North India & $£ 313188$ \\
\hline $\begin{array}{l}1913 \text { Sister Alison \& Māori } \\
\text { Mission }\end{array}$ & $\begin{array}{l}\text { Māori } \\
\text { Mission }\end{array}$ & $£ 60$ & $\begin{array}{l}1932 \text { Reporoa church } \\
\text { building }\end{array}$ & $\begin{array}{l}\text { Māori } \\
\text { Mission }\end{array}$ & $£ 327105$ \\
\hline 1914 Dr Bowie microscope & New Hebrides & $£ 82126$ & 1933 Kong Chuen hospital & $\begin{array}{l}\text { South } \\
\text { China } \\
\end{array}$ & $£ 31844$ \\
\hline 1915 Indian wells & North India & $£ 105136$ & 1934 Jagadhri hospital & North India & $£ 266159$ \\
\hline 1916 China school room & South China & $£ 106$ & $\begin{array}{l}1935 \text { Home mission } \\
\text { church at Okaihau }\end{array}$ & $\begin{array}{l}\text { New } \\
\text { Zealand }\end{array}$ & $£ 288510$ \\
\hline $\begin{array}{l}1917 \text { Alice Henderson } \\
\text { boys' work }\end{array}$ & North India & $£ 155187$ & $\begin{array}{l}\mathbf{1 9 3 6} \text { X ray, Kong Chuen } \\
\text { hospital }\end{array}$ & $\begin{array}{l}\text { South } \\
\text { China } \\
\end{array}$ & $£ 40865$ \\
\hline $\begin{array}{l}1918 \text { NZ Presbyterian } \\
\text { orphanages }\end{array}$ & New Zealand & $£ 176140$ & $\begin{array}{l}1937 \text { Support for Revd } \\
\text { Crump }\end{array}$ & \begin{tabular}{|l|} 
New \\
Hebrides \\
\end{tabular} & $£ 378152$ \\
\hline 1919 Ruatahuna Dispensary & $\begin{array}{l}\text { Māori } \\
\text { Mission } \\
\end{array}$ & $£ 264107$ & $\begin{array}{l}\mathbf{1 9 3 8} \text { Car for India } \\
\text { missionaries }\end{array}$ & North India & $£ 411166$ \\
\hline $\begin{array}{l}1920 X \text { ray machine for the } \\
\text { new Kong Chuen hospital }\end{array}$ & South China & $£ 336151$ & $\begin{array}{l}1939 \text { Waikaremoana } \\
\text { church building }\end{array}$ & \begin{tabular}{|l|} 
Māori \\
Mission \\
\end{tabular} & $£ 45579$ \\
\hline 1921 Missionaries in India & North India & $£ 3501410$ & $\mathbf{1 9 4 0}$ New Hebrides & \begin{tabular}{|l|} 
New \\
Hebrides \\
\end{tabular} & $£ 64010$ \\
\hline $\begin{array}{l}1922 \text { Tongoa - hurricane } \\
\text { repairs }\end{array}$ & New Hebrides & $£ 30316$ & $\begin{array}{l}1941 \text { Infrastructure (incl. } \\
\text { Turakina Girls' school) }\end{array}$ & $\begin{array}{l}\text { Māori } \\
\text { Mission } \\
\end{array}$ & $£ 69003$ \\
\hline 1923 Home mission work & New Zealand & $£ 319128$ & $\begin{array}{l}1942 \text { Lower Hutt - church } \\
\text { for new suburb }\end{array}$ & \begin{tabular}{|l|} 
New \\
Zealand \\
\end{tabular} & $£ 73000$ \\
\hline $\begin{array}{l}1924 \text { Kong Chuen boys' } \\
\text { school }\end{array}$ & South China & $£ 29609$ & $\begin{array}{l}\mathbf{1 9 4 3} \text { Rebuilding war- } \\
\text { damaged mission } \\
\text { buildings }\end{array}$ & $\begin{array}{l}\text { South } \\
\text { China }\end{array}$ & $£ 100526$ \\
\hline 1925 Kharar High School & North India & $£ 303134$ & $\begin{array}{l}1944 \text { 'Memorial and } \\
\text { Thanksgiving' fund }\end{array}$ & $\begin{array}{l}\text { New } \\
\text { Zealand } \\
\end{array}$ & $£ 1150130$ \\
\hline $\begin{array}{l}1926 \text { Presbyterian } \\
\text { orphanages }\end{array}$ & New Zealand & $£ 283148$ & $\begin{array}{l}1945 \text { Kharar High School } \\
\text { land purchase }\end{array}$ & India & $£ 110130$ \\
\hline $\begin{array}{l}1927 \text { Indian children in } \\
\text { Jagadhri and Kharar }\end{array}$ & North India & $£ 29000$ & & & \\
\hline
\end{tabular}

${ }^{8}$ Details for projects and contributions come from: The Break of Day, 1909-1945; and Mission Committee Reports, Proceedings of the General Assembly of the Presbyterian Church of New Zealand, 1942-1945. 


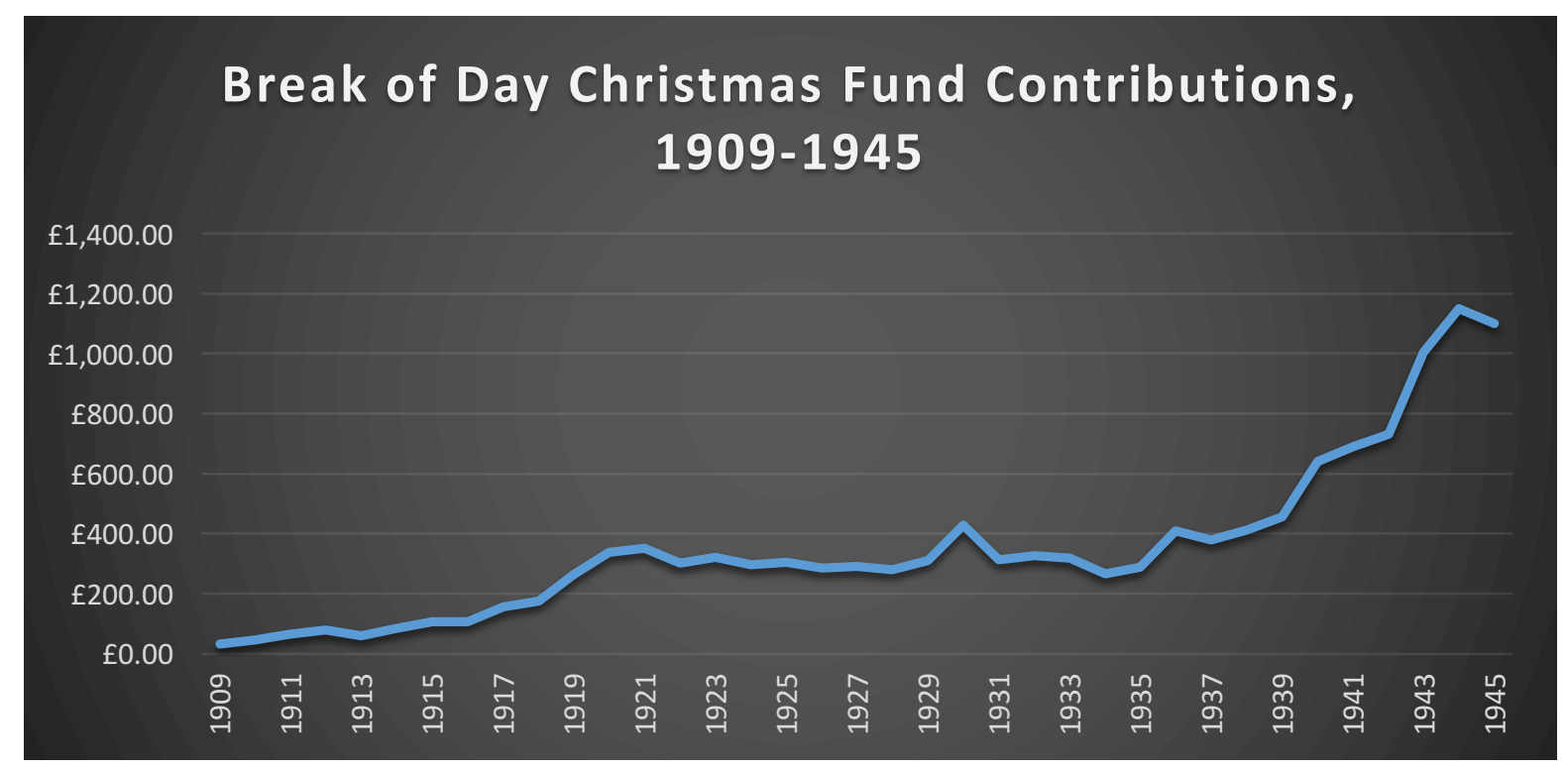

Figure 3: Annual Break of Day Christmas Fund Contributions, 1909-1945

Scrutiny of selected contribution lists and of Table 1 indicates the changing 'geography' of giving. On the one hand, support shifted from southern regions to a more nationally representative constituency. In 1911 just over three quarters of contributions came from individuals or groups in New Zealand's South Island (especially from Otago and Southland), with a strong rural focus. By 1960 contributors were almost evenly spread between north and south and came from a more representative mix of urban and rural settings reflecting significant national demographic shifts ('Christmas Present Contributions' February 1911, p. 16; “"Break of Day” Christmas Gift', March 1960, p. 16).

On the other hand, projects focused deliberately and systematically on the five geographic sites of Presbyterian missionary investment, but to varying extents (Figure 4). There was a clear policy to maintain fair coverage of each, although circumstances (especially the response to natural disasters or the impact of war) sometimes dictated the focus. The Chinese and Indian missions were more costly ventures and they possibly evoked an emotional 
response that lead to higher giving. Furthermore, the New Hebrides had become a much reduced focus in terms of personnel and priorities by the 1940s. At the same time generous responses to domestic needs (including Māori Mission projects) indicated that children were willing to sustain their contributions irrespective of the location.

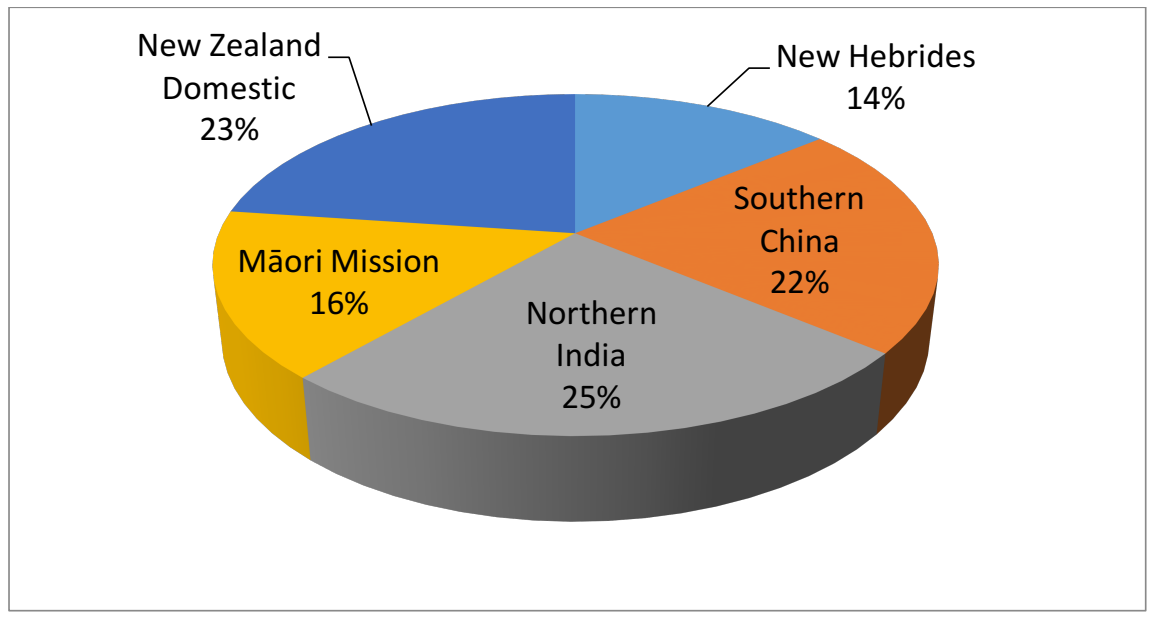

Figure 4: Distribution of Break of Day Fundraising, 1909-1945

Schemes like the Christmas fund indicate that children's charitable activity was important to New Zealand Protestants. It fitted into a broader framework of children's charity that included a missionary focus. Between 1905 and 1920 national Sunday schools were regularly contributing annual totals of between $£ 1200$ and $£ 1500$ to missions, increasing to between $£ 2000$ and $£ 3000$ during the 1920s. Equivalent amounts were donated by other children’s or young peoples' groups within the national Church (YOCC 1906, p. 234; 1920, p. 122; 1929, p. 120). By the 1920s these figures made up around one third of Sunday school giving and between a half and two thirds of adolescent giving (Morrison 2016, p. 170). While it is unclear whether or not the Christmas present money was calculated within these figures, even 
so the annual totals reached by the 1930s represented a significant proportion of juvenile Presbyterian giving to missionary and other causes.

In turn, this charitable activity was not focused solely on fundraising. It was underpinned by a clearly articulated rationale which emphasised the theological and moral efficacy of juvenile charity. In the rhetoric of the period, financial giving should ideally and ultimately reflect internalised habits of heart and mind that both manifested devotion to God and expressed an ethos of sacrificial service. Thus Aitken's suggestion to children that 'if we send [the Chinese] a gift at Christmas it will count just the same as if we sent it to Him [Jesus Christ]' ('Editorial' October 1909, p. 2) had a wider context. It reflected an entrenched theological discourse emphasizing character and citizenship formation. In part this was linked to wider notions of imperialism and to nascent national loyalties operating in New Zealand society by the late nineteenth century (Keen 1999). It also had a longer genealogy stretching back to southern Free Church of Scotland settlement from 1848, wherein the concern was to develop a civil society shaped by godly thought and practice (Otago Southland Proceedings 1866, pp. 8-9). More specifically, educators and leaders hoped that attitudes and habits formed in childhood would influence children's lives and priorities as adults and future members of the church, and that children would also, as children, develop 'wide sympathies' and discover now the 'joy and heroism of doing good' ('Financial Secretary's Report', 1919, p. 29; Waddell 1884, pp. 44-49). This 'heroic' element was by no means an isolated one, being replicated in both sermons and wider religious literature of the period for children in places like New Zealand and Canada). ${ }^{9}$

\footnotetext{
${ }^{9}$ Waddell 1916, ‘Children's Talks'; Morrison 2017; Trepanier 2017; Troughton 2017.
} 
One final trend previews discussion in the following section: the discernible shift from individual giving to the institutionalisation of the Christmas fund. In the early years Aitken reprinted information from individual girls and boys who had creatively found ways of raising money for each year's project. Typically that included things like: domestic tasks (housekeeping, gardening, wood chopping, fetching coal); child minding; sewing and making clothes (girls); shepherding and catching rabbits (boys); selling things; 'learning by heart the books of the Bible'; stamping account books; making breakfast; 'doing without sugar on porridge'; and 'not getting cross for a whole week' ('Letters to Editor' 1909, p. 15). The list became increasingly long, varied and inventive. In 1911 two thirds of all contributions came from such individuals or families. Over the next twenty years that began to change. By 1936 giving was predominantly channelled through two Church institutions - Sunday schools and Busy Bee groups - which provided 96 per cent of the total Christmas present fund; only 4 per cent of donations came from individuals ('Christmas Present Contributions' 1911, p. 16; 'Christmas Gift Fund for Okaihau' 1936, pp. 12-13). Money raising schemes were both individual and collective, like the entertainment evening and garden parties run by the Balfour Busy Bees in 1927 ('Balfour Busy Bee Report' 1928, p. 15), or the two unnamed boys who raised money for a Māori Mission church at Waikaremoana in 1939 ('The Christmas Gift' 1940, p. 3). While the details were still reprinted as letter extracts they were almost exclusively reported in institutional terms. The identities of individual children were elided in the process.

\section{Juvenile Missionary Literature, Charity and the Formation of Community Identity}

In the light of these data, then, what sense do we make of settler Protestant children's charitable relationship to overseas missions and what is significant about how this was represented through religious magazines? In this section, I examine the function of 
missionary magazines in facilitating community formation through charitable activity. In the period under consideration religion and literature were harnessed for their didactic potential to shape young lives, and as a lucrative marketing focus as middle-class childhood and youth emerged as a key site of commercial exploitation (Denisoff 2008; Greenspoon 2017). From a philanthropic angle literature was an important means by which messages about charity could be consolidated in children's minds. In British-world literature, including books with a missionary theme or focus, this didactic function had a long lineage running from the eighteenth to the early twentieth centuries. Margot Hillel's observation (based on Anna Davin's work on British juvenile literature) - that fictional literature emphasised 'that children needed to be moulded as charitable beings who would consider the poor, give generously and learn lifelong lessons in order to become charitable adults' (Hillel 2017, p. 163; Davin 2001) - offers conclusions that can also be drawn from the discourses operating in colonial Protestant settings like New Zealand.

In the case of the Christmas present fund, however, the symbiotic relationship between the activity and the medium through which it was promoted was significant. In particular the specific form, function and influence of children's missionary magazines force us to differentiate carefully the concept of 'charitable literature' and how children related to it. Josef Altholz has identified the nineteenth century as a key historical moment in which 'the periodical press [was established] as the preeminent medium of communication on all subjects, secular and religious. It became the rule that every movement, every school of thought, every sect, and every party had to have at least one periodical organ of expression' (1989, p. 1). While historians have been slow to acknowledge this, over the last two decades that attitude has begun to change in at least two ways. There is now a useful body of contextualised work that emphasises periodical literature both in terms of its importance as a 
historical source and as a discursive influence in the late nineteenth- and early twentiethcentury context. ${ }^{10}$ Periodicals also have been taken seriously by historians of empire, colonialism and migration given the importance of the nineteenth century in particular as a moment of convergence between these forces and the rapid emergence of periodical literature. ${ }^{11}$ Isabel Hofmeyr draws attention to a great 'swirl' $(2014$, p. 4) of periodical literature that was in global circulation at any one time. Magazines 'poured' (Hofmeyr 2014, p. 4) out of places like London to the rest of the empire as well as being produced locally in a host of colonial contexts. These circulated in whole and in parts, with elements cut and pasted and re-printed in a myriad of imperial settings. This "warp and weft of "periodicalism" in empire' in turn created an influential 'imperial textual field'; more particularly an 'imperial textual commons' constituted by a 'weave of uncopyrighted text that criss-crossed empire' and which became pervasive across a vast reading audience (Hofmeyr 2014, pp. 6-7).

The British periodical press became increasingly popular in the eighteenth century amongst the wider reading public. ${ }^{12}$ Altholz suggests that British children's periodicals were 'virtually invented in the nineteenth century' and, up to at least the 1860 s, 'were all religious in tone and intent' (1989, p. 138). By 1900 children's religious and missionary magazines were ubiquitous, cheap, accessible and effective forms of literature across the British world including the settler colonies - and were well regarded as a pedagogical tool alongside their more popular functions (Morrison 2015a, pp. 137-138). In the missionary context they were one part of a 'vast' body of 'literature created for informing and instructing' Western supporters of global missions (Schoepflin 2005, p. 569) which equate very well to Hofmeyr's

\footnotetext{
${ }^{10}$ For example: Jensz and Acke (eds.) 2013; Olsen 2009; Platt 2015.

${ }^{11}$ For example: Hall 2002; Johnston 2003; Lester 2001.

12 Altick 1957, pp. 47-48, 351-2, 357-8, 391-6; Galbraith 1997; Vann and VanArsdel (eds.) 1995.
} 
notion of a 'textual commons', this time marked by religious as well as imperial connections. These children's religious magazines functioned as a specific literary genre that helped to evoke 'emotional attachment', provided 'tools of identity and community building', and acted as a source of 'authoritative knowledge' for their readers (Acke 2013, p. 242).

These functions were all evident in The Break of Day. The Christmas present focus, however, further differentiates missionary (and other religious) magazines both from their adult counterparts and from general juvenile religious literature, since they acted more specifically as interactive texts through which children were active and publicly heard (albeit through adult editorial redaction). Indeed it might be argued that without children's avowed interest and involvement, many of these magazines would not have lasted as long as they did. Children and children's lives were central to many missionary periodicals' raison d'être. Whereas books of fiction and non-fiction laid out key moral and ethical messages about how to live, missionary periodicals both invited children to read and respond to these messages and provided them with a vehicle by which to do so. In the process they helped to create a sense of shared collective identity. This challenges scholarship that has previously downplayed children's agency in nineteenth-century children's literature. Susan Ash argues that Dr Barnardo, for example, 'actively mobilised [his] constituency of potential workers precisely at a time ... that is marked by the absence of child agency, particularly in this socalled "Golden Age" of children's literature' (2016, pp. 121-122). She notes that this was evident through Dr Barnado's 'print media for children' and that this may well date back to late eighteenth-century religious tract literature that clearly 'conscripted children to work for evangelical purposes in the home and local communities' (Ash 2016, p. 122).

Ash certainly is not alone in making this claim. In the missionary context a precedent was set as early as the 1840s, when the London Missionary Society's Juvenile Missionary 
Magazine enlisted English children's support to raise funds for the mission ship John Williams in the South Pacific, and actively encouraged their participation in the life of the magazine itself. As Michelle Elleray (2011) indicates, this was innovative both in terms of literary form and wider conceptions of children's charitable potential. Magazines began to draw children into a more direct relationship with missions and their subjects thereby enabling children to adopt a 'dialogic relationship' with their world and becoming 'active agents' who might effect a difference in their or others' worlds (Elleray 2011, p. 232). This was the 'cultural shift' that she posits more broadly for Victorian children, cited earlier in the Introduction.

By the early 1900s that 'cultural shift' had become the accepted norm, of which The Break of Day and its annual Christmas present fund were one concrete expression. From the outset the magazine's editorial intent was to engage children actively and emotionally to help them feel included and valued both for who they were and what they could contribute. This helped to create a cohesive community of readers that was both imagined and national in scope. The Christmas present scheme was a circumscribed yet tangible way by which this ethos might be consolidated. The extent to which Aitken genuinely valued his readers was evident in 1935 when the editorship changed hands. McDiarmid wrote that he was 'very nervous about trying to take up the work that Mr Aitken is laying down' and that he would do his 'best for the BREAK OF DAY' and 'to make it interesting to you all' ('Editorial' April 1935, p. 1). He promised to maintain its standard and approach, but he also exhorted children to contribute in ways that would consolidate and extend a sense of readers' collective identity:

I am expecting that you girls and boys will help your new Editor as you have helped Mr Aitken. Read your BREAK OF DAY, talk about it, "boost it," get more people to take it and read it, and when something is suggested that you can do - like working for 
a BREAK OF DAY Christmas Gift - then get to it with a will, and show that you are true BREAK OF DAY readers and workers. ('Editorial' April 1935, p. 2)

If we accept this way of conceiving juvenile missionary magazines and the charitable activity that they engendered, then we can probe the significance of a specific scheme (like the Christmas present fund) beyond the immediate and implicitly important aims of raising juvenile money or moral consciousness. For example, in writing about nineteenth-century European Catholic children Heywood suggests that the wider 'phenomenon of children's missionary societies' was also 'much more than tapping a rich source of income, or even fostering the missionary spirit in the young' (2015, p. 461). Their significance lay in 'wider anxieties about the role of religion in the family, childhood and in civil society as western polities were modernizing and secularizing in the nineteenth century' (Heywood 2015, p.461) In the process 'power structures were re-conceptualized' and 'social bonds were altered and reimagined' (Heywood 2015, p. 461).

Heywood's thesis raises a key issue for the study of children and 'foreign' or overseas missions: the reflexive role of overseas missions in shaping domestic lives and mind sets. This theme is critical for understanding the impact of the wider missionary movements of this period. ${ }^{13}$ Furthermore, as Heywood's European case indicates, the focus on reflexivity also demands a careful elucidation of particular domestic sites, rather than making generalisations across space and time. How, then, might this be conceptualised further for the colonial New Zealand Presbyterian setting? Different dynamics and priorities were operating: a young frontier society coming to grips with its legacy of being 'British'; its place in the world (both regional and global); and the already complicated and extremely muddied politics of being bi-racial if not bi-cultural. The 'significance' of both the message and its medium might usefully be probed with respect to notions of settler Presbyterian identity and of community

${ }^{13}$ See further Morrison 2016. 
formation. In particular, it is apposite to ask how children were included, how was that expressed and what changed over time?

Break of Day readers were interactively engaged by Aitken (and later McDiarmid) through the magazine, which was enhanced over the years by membership in a Birthday Book Club and involvement through the Christmas present scheme. The community that emerged could be readily identified based on readers' names, gender and geographical location. The growing numbers of children involved within the magazine's first decade obviously enjoyed themselves and readily communicated this through their letters. Their letters also attest to their appreciation of being acknowledged and the opportunity to make a difference at home and abroad, as well as reflecting their trust in the editor. All of this was important given New Zealand's attenuated geography and the continued existence of many isolated rural communities or smaller towns. Both the magazine and charitable activity became key ways in which Presbyterian children might identify with and hear from each other. In other words the medium, its message, and the charitable activity that it generated each acted together to create a particular form of imagined community whose contours were both civic and religious. That community was one which embraced individuals from varied circumstances, which accentuated a theology of activism and self-sacrifice while repackaging this within commonly accepted intellectual and emotional parameters, and which imbricated children in a wider community of Protestant youngsters that was both transdenominational and transnational in scope. ${ }^{14}$ At its heart, however, it provided a key means by which to help children think of themselves as 'Presbyterian', and to activate the culture of 'care' espoused by McKenzie in the first editorial in 1909. This was critical, not

\footnotetext{
${ }^{14}$ On these themes see further: Hofmeyr 2014; Morrison 2015c; Vallgårda, Alexander \& Olsen 2015.
} 
just for the longevity of Presbyterian missionary support and profile, but also for reshaping a national settler Church out of its previous constituent, and often fractured, parts.

Over time this community became demonstrably more institutionalised. In its 1940 report the FMC recorded its 'deep gratitude to the children of the Church, Sunday School scholars, Busy Bees and individuals, together with Superintendents and Teachers who organised the Break of Day Christmas Gift for 1939' (FMC 1940, p. 73). By the 1940s this imagined community that embraced thousands of children had become somewhat more amorphous, drawing on wider Sunday school resources and personnel for its maintenance. More specifically both the magazine and charitable focus became intimately associated with the Busy Bees movement. In 1910 sisters Muriel and Dorothy Laishley, from a minister's family in the southernmost port town of Bluff (near Invercargill), formed their own missionary support group, raising money through putting on entertainment. On their mother's suggestion they called themselves the 'Busy Bees'. They wrote to Aitken and soon became a household name through the magazine's pages (Figure 5).

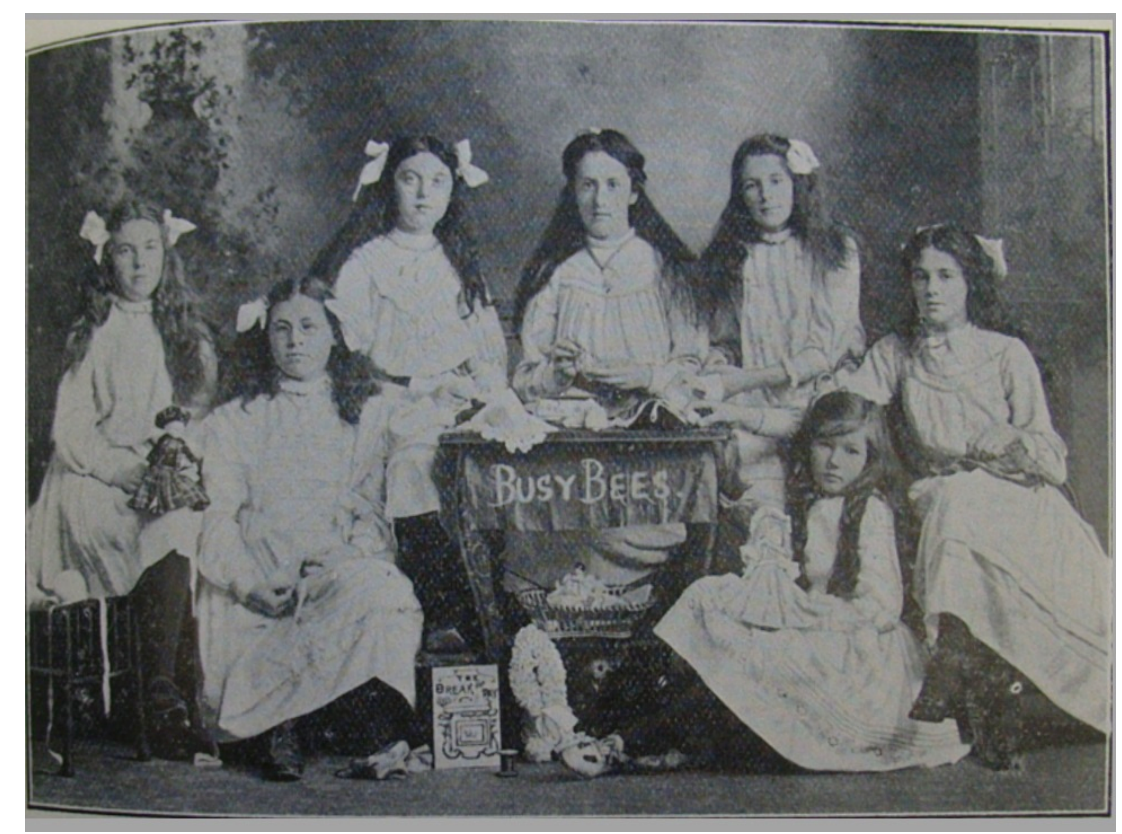


Figure 5: The Original Busy Bee Hive, Bluff, c.1910 (BoD, July 1910, p. 7) (Presbyterian Research Centre (Archives) - used with permission)

Within a year the group was being replicated in other parts of the country. Aitken reported enthusiastically, for example, that apart from the 'parent hive' at Bluff there was 'a swarm at Queenstown, and another at Waipawa ... and at Orepuki' ('Editorial' February 1911, p. 3). He asked for news of other groups and hoped that he would 'hear of hives swarming all over the country' ('Editorial' February 1911, p. 3). Within a decade, Busy Bees was established as a national 'children's movement' in its own right (Barber 1990, p. 75), constituted of approximately 150 groups (nicknamed 'hives') and collectively identified by the motto 'The Whole Wide World for Jesus' (Laishley 1960, pp. 4-5). Typically each group was associated with a specific Presbyterian parish, acting in an adjunct role to existing Sunday schools, focusing children on mission (Figure 6).

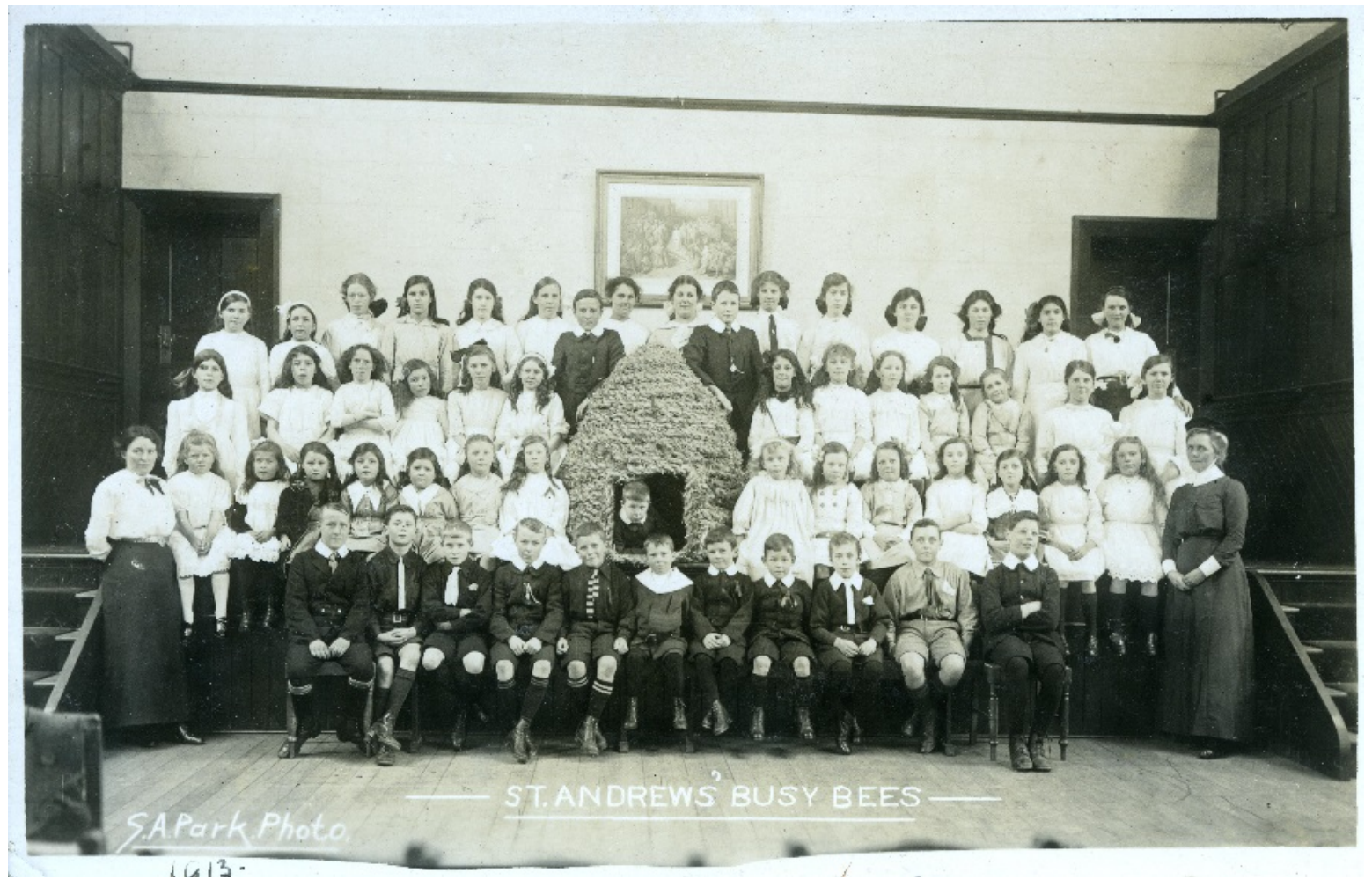


Figure 6: Busy Bee Hive, St Andrew's Presbyterian Church, Dunedin, c. 1910 (Presbyterian Research Centre (Archives), P-A62.7-21 - used with permission)

Textual and photographic evidence from the Break of Day reveals a wide range of rural and urban groups embracing children and young teenagers working together, with the older ones often acting in a leadership capacity. Group activities were many and varied, typified by the St Andrew's (Dunedin) group who in 1918 reported:

Weekly meetings held for Bible lessons; missionary talks about our Mission Fields; honey making; honey of various kinds gathered, such as bandages, children's garments, golliwogs (made from old stockings), enamel basins, pencils, writing pads, and dressing gauze, all to be sent to the Kong Chuen hospital ('Busy Bees' Reports', $B o D$, November 1918, p. 5).

Activity was typically focused around a didactic function (learning about missions) and practical outputs (supporting local and overseas missions through a miscellany of projects and events). Making things to sell (in order to raise money for targeted projects including the Christmas present fund) featured significantly among all of this - both at home and together at meeting times - and having fun in the process was important. Over time there emerged a distinct emphasis on children developing habits of systematic self-sacrifice or self-denial on behalf of others, both at home and in the group context. Comparisons of group reports from the 1910 s to the 1950 s indicate that there was significant continuity in the tasks carried out and in the underlying functions or rationale of the groups. Gender-wise it is difficult to be categorical about membership because of the lack of differentiated data. As 'hives' became more aligned with Sunday schools (see below) we might speculate that they reflected a broader demographic. Routinely boys made up just under half and girls just over half of 
national Sunday school attendance figures up to 1940 ('Youth of the Church Statistics', YOCC, 1905-1940). However, individual Busy Bees group photographs suggest that boys might have been in the minority, often making up no more than 25 per cent of children represented and, in some cases, entirely absent $(B o D, 1910-1930)$. While group reports usually referred to generic 'children' or 'bees', there were glimpses of individuals who fulfilled gendered roles: in the Riversdale group Douglas Wright was treasurer alongside Frances Gordon as secretary; in Knapdale 'one little chap and his brother intend growing some potatoes for the Orphanage'; and in both Clinton and Clandeboye members (presumably girls) were 'sewing' items for sale. Sometimes hives were constituted along gender lines, as in the case of the Kaiapoi boys' and girls' hives which met separately while focusing on an agreed project and combining for annual meetings ('Busy Bees' Reports' November 1918, pp. 6-7, 12).

In reality the energies of this 'children's movement' were quickly corralled by adults and its activities aligned with denominational mission priorities. Busy Bee groups were organised regionally and nationally under the aegis of the Presbyterian Women's Missionary Union and their national profile enhanced by regular photographs and reports in The Break of Day. In turn Busy Bees readily adopted the Christmas present scheme as an annual charitable focus, which might explain further the sustained giving over so many years. In the process Busy Bees, Break of Day and the Christmas scheme became synonymous. By the 1920s fundraising efforts were routinely communicated in the name of Busy Bee groups, rather than by named individuals. Lists of financial supporters, too, predominantly became lists of Sunday school and Busy Bee groups. It is thus possible to speculate that while at the local level greater organization of charitable giving afforded financial efficiencies and played up the social benefits of working together, at the national level children's sense of communal 
belonging became more de-personalised, and that their gaze became more parochial in the process; for the children involved, perhaps, there was something gained and something lost.

Finally it is legitimate to ask 'who belonged' in this imagined community that was constituted through both text and charitable activity. In other words, to what extent was it a differentiated community? It is possible to partially reconstruct the community's membership by gender, rural or urban location and even age. With increased institutionalisation the geographical distribution of giving can still be mapped, but not the more personal features. The relative silence around race, in the rhetoric of the Christmas scheme, brings this question of 'who belongs' into sharper focus. Where the silence is broken, ambiguities abound.

In 1927 a Busy Bee group on the New Hebrides island of Nguna reported its activities, accompanied by a photograph (Figure 7). This group was outwardly focused: raising money for a hospital in the capital Vila; financially supporting island adults working as missionary teachers in other New Hebrides islands; making 'fans, baskets, mats etc.' to sell; and sending money for the 1926 Christmas focus on Presbyterian orphanages in New Zealand (Milne, BoD, February 1927, p. 5). 


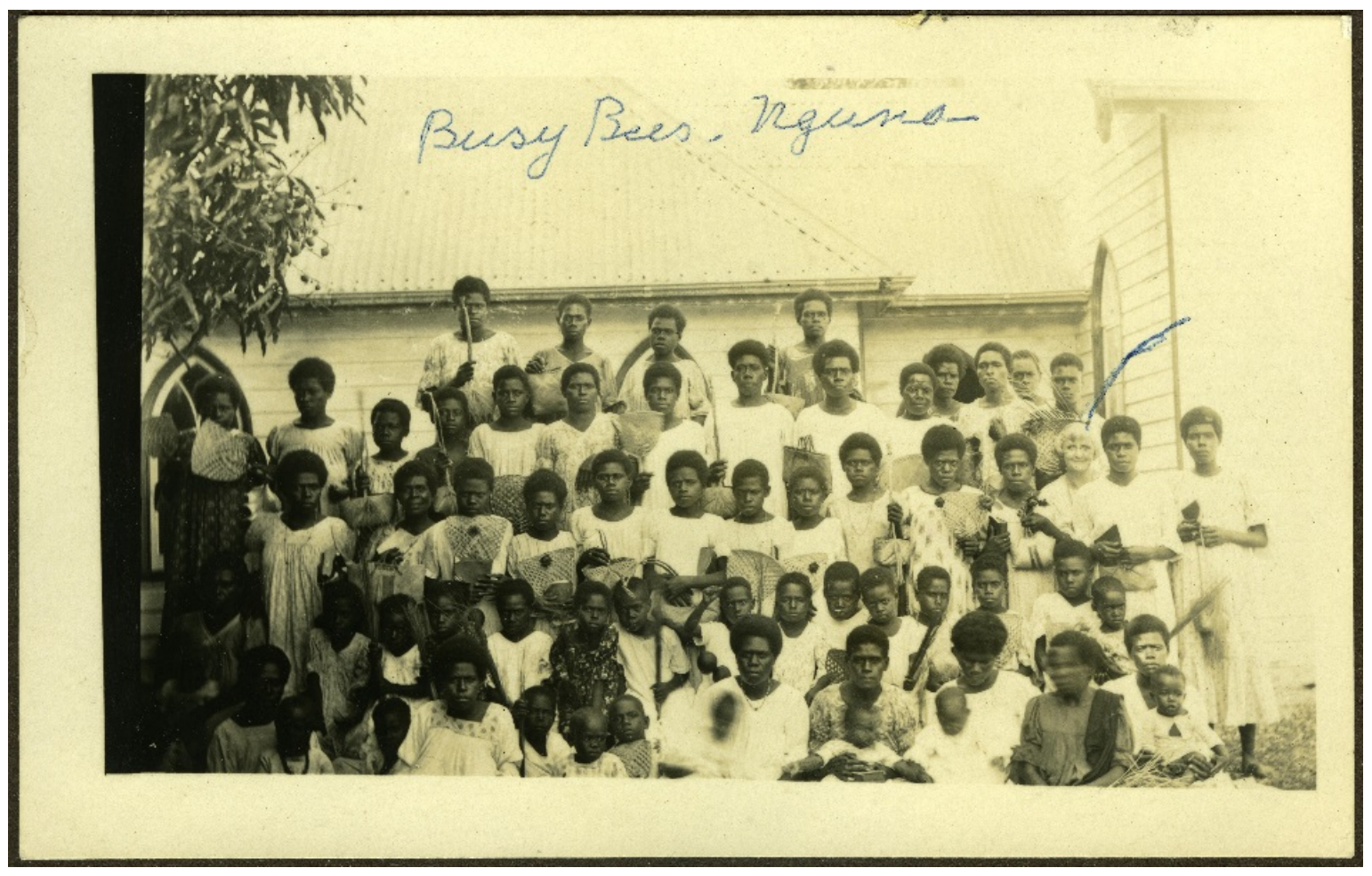

Figure 7: Busy Bee Hive, Taloa Church, Nguna, New Hebrides [Vanuatu], 1926 (Presbyterian Research Centre (Archives), A-S30-163.19-20 - used with permission) 
Both the photograph and article were prefaced by Aitken's comment that:

I'm quite sure that [this group] works as hard, and does as well as any of our hives at home. .... I fancy the red tongues inside those black faces wag hard all the time, and I daresay those black babies crow. What a jolly old row there will be. Anyhow, we all send our kindest greetings to the Nguna Busy Bees, and hope they will continue to gather honey for many years and to share in our Christmas Present.

('Editorial', February 1927, p. 4)

This group was barely a year old (nearly twenty years on from the magazine's and Busy Bee's inception) and it was still overseen by a second-generation missionary (Jemima Milne), even though missionaries had been on Nguna since the 1860s and the local Christian community was well established. While this group reappeared in the scheme's statistics over subsequent years, it was the only one outside of New Zealand and one of very few instances when 'missionary subjects' were represented to readers as being givers and, by implication, equals.

On the surface this community constituted by the Break of Day potentially was racially or ethnically diverse, embracing all as equals under God. As the New Hebrides example indicate, however, the reality was probably more complex; forces of colonialism and imperialism further defined this community whether intended or not (Salesa 2009). The Break of Day correspondence contains no references to the Nguna community from its child readers so we do not know how they 'read' or reacted to the photograph and text. They were predominantly white, British-settler children who routinely consumed information and images that differentiated their world from that of other peoples.

Often this content related to people in other parts of the world, including those in the photograph from Nguna. But it also included indigenous Māori closer to home. That Māori Christians supported overseas missions more broadly is evident in the many references to 
indigenous communities raising money or taking a missionary interest in the pages of the Anglican Māori newspaper Te Pipiwharauroa: He Kupu Whakamarama (1898-1901). These were well-established Christian communities of many decades. By way of contrast, Presbyterian mission work among Māori only properly dated from around 1907, wherein Māori were still conceived of as missionary subjects and therefore as worthy recipients of charitable projects like the Christmas present fund. Between 1914 and 1934, fifteen different mission stations were begun among communities of the central and eastern North Island (Paterson 2012, pp. 188-93). Children were a key focus of these projects, and both day and Sunday schools were important ways of working with children. Māori children must have been prompted to take an interest in and support missions, but the evidence gleaned from The Break of Day is fragmentary at best. There are references, for example, to Sunday schools at Opotiki and Te Whaiti (both mission stations) contributing to the Christmas present fund, and to active Busy Bee groups at Turakina Māori Girls' College and at Maranui lead by Sister Jessie Alexander ('Busy Bees’ Reports' February 1936, p. 18; March 1960, p. 16; November 1920, pp. 9 and 10). More representative, however, was Sister Jessie's reference in 1931 to a group of 'our Maori [sic] children' and her expectation that 'by and by we shall have our Maori Busy Bees, too, for they are lovely children and so eager to help any good work' (Jessie 1931, p. 8). Over the longer duration of the early to mid-twentieth century, in the magazine's pages, both Māori adults and children continued to be regularly represented in terms of geographical isolation, cultural difference and social disadvantage, and as the recipients of Western Christian progressivism (Morrison 2012, pp. 159-178). Categorical racism may not have been intended, and indeed possibly did not exist in wider communities where Māori and Pākehā children routinely rubbed shoulders (Graham 1992, pp. 19-20). But for those participating in this virtual community, the differences probably existed nevertheless, emphasised through the charitable activities of the community and inscribed on 
hearts and minds in ways that possibly lasted for generations. The 'formation of prejudice', for example, may have been one of the unintended but enduring legacies of the missionary movement amongst children, in New Zealand as elsewhere. (Prochaska 1978, pp. 110, 113 14).

\section{Conclusion}

In bringing this essay to a conclusion the previous discussion on race and (more implicitly) both colonialism and colonisation is apposite. In the context of examining missionary texts Anna Johnston notes that historical 'missionary work, particularly in colonial contexts' and in relation to imperialism, is variously regarded from a range of critical, celebratory and more neutral stances, but that 'nineteenth-century missionaries were in fact highly conscious of the nature of their evangelical projects and their potential effect, both in colonial cultures and back in the imperial metropolis' $(2003$, p. 2). In this respect she notes that they were 'prolific writers' (including for children) and that their 'texts are crucial to understanding crosscultural encounters under the aegis of empire because they illuminate the formation of a mode of mutual imbrication between white imperial subjects, white colonial subjects, and non-white colonial subjects' (Johnston 2003, p. 3). Texts, in this case written and published, are thus important to consider both as source types and as discursive vehicles. Children's texts, in relationship to historical missions, are not always considered within the historiography, although that state of affairs is beginning to change. Children as colonial actors become much more obvious when the specific genre of the missionary magazine is analysed and their charitable activities considered. In the colonial setting considered here, albeit with a focus on settler children rather than those from indigenous communities, magazines like The Break of Day, and the charitable schemes that they promoted, helped to form religious communities of children that were potentially unbounded and inclusive. In the 
New Zealand context they brought thousands of children together, over many years and many miles, to focus on a world beyond themselves. I have argued that their main legacy was to meld children into a community defined by denomination and national interest. Yet they also brought them into contact with other children and communities, beyond their shores and outside their cultural frames of reference. They helped to form a community of individuals and groups shaped by theological, emotional, cultural and social imperatives focused around self-sacrifice and generosity. At the same time, however, they also helped to form communities of children that were more tightly circumscribed than was intended, and who may have differentiated between 'them' and 'us' despite editors and other adults' best efforts.

\section{Acknowledgements}

The research for this article was partly supported by a University of Otago Research Grant and sits within a larger project investigating the relationships between New Zealand and Scottish Presbyterian children and the missionary movement in the late nineteenth and early twentieth centuries. I thank the staff of the Presbyterian Research Centre (Archives), Dunedin, for generous access to copies of The Break of Day plus other archival materials that provide wider context; and for permission to include selected images from these collections. I also gratefully acknowledge both the helpful and constructive comments of the two anonymous readers who reviewed the initial draft and the journal editor's direction and support. 
Papers 24.2 (2016)

\section{References}

\section{Primary Sources}

'Balfour Busy Bee Report' 1928, The Break of Day, March, p. 15.

'The Break of Day in the New Hebrides' 1935, The Break of Day, November, p. 3.

““Break of Day” Christmas Gift' 1960, The Break of Day, March, p. 16.

'Busy Bees' Reports' 1918, The Break of Day, November, p. 5.

'Busy Bees' Reports' 1920, The Break of Day, November, pp. 9-10.

'Busy Bees' Reports' 1936, The Break of Day, February, p. 18.

'Busy Bees’ Reports' 1960, The Break of Day, March, p. 16.

'The Christmas Gift' 1940, The Break of Day, February, p. 3.

'Christmas Gift Fund for Okaihau' 1936, The Break of Day, February, pp. 12-13.

'Christmas Present Contributions' 1911, The Break of Day, February, p. 16.

'Farewell to the Rev. James Aitken' 1916, Otago Daily Times, March 2, p. 6.

'The Dayspring' 1884, Otago Daily Times, 29 February, supplement, p. 2.

'Editorial' 1909, The Break of Day, August, pp. 1-2.

'Editorial' 1909, The Break of Day, October, pp. 1-2.

'Editorial' 1909, The Break of Day, November, pp. 1-3.

'Editorial' 1910, The Break of Day, April, p. 2.

'Editorial' 1910, The Break of Day, August, pp. 2-3)

'Editorial' 1911, The Break of Day, February, p. 3.

'Editorial' 1912, The Break of Day, February, p. 1-2.

'Editorial' 1927, The Break of Day, February, p. 4.

'Editorial' 1935, The Break of Day, April, p. 1.

'Financial Secretary's Report' 1918-1919, New Zealand Baptist Union Handbook, 1919-1920 
Foreign Missions Committee Reports [FMC], Proceedings of the General Assembly of the Presbyterian Church of New Zealand, 1908-1941

Foreign Mission Committee Minutes, 1908-1911, Foreign Missions Committee Book, 19011913, GA0001, Presbyterian Research Centre, Dunedin, New Zealand Jessie, Sister 1931, 'Among the Opotiki Maoris', The Break of Day, November, p. 8. Laishley, M 1960, 'The Beginning of Busy Bees', The Break of Day, March, pp. 4-5.

'Letters to Editor' 1909, The Break of Day, November, p. 15.

McKenzie, Revd John 1909, 'Open Letter to Children', The Break of Day, February, pp. 1-3. Milne, Mrs WV 1927, 'Busy Bees on Nguna', The Break of Day, February, p. 5.

Mission Committee Reports, Proceedings of the General Assembly of the Presbyterian Church of New Zealand, 1942-1948

Overseas Mission Committee Reports, Proceedings of the General Assembly of the Presbyterian Church of New Zealand, 1949-1960

Proceedings of the Synod of the Presbyterian Church of Southland and Otago [Otago Southland Proceedings], 1866-1901

Sunday School Committee Minutes, 1907-1910 [Sunday School Minutes], Sunday School Committee Minute Book, 1907-1919, AD 12/14, Presbyterian Research Centre, Dunedin, New Zealand

Waddell, Revd R 1884, ‘The Sabbath-school and Missions', New Zealand Missionary Record, February, pp. 44-49.

Waddell, Revd R, ‘Children's Talks', c. 1906-16 [unpublished children's sermons], Personal Collection, 394/8, DC1/4, Presbyterian Research Centre, Dunedin, New Zealand Youth of the Church Committee Reports [YOCC], Proceedings of the General Assembly of the Presbyterian Church of New Zealand, 1908-1940 


\section{Secondary Sources}

Acke, Hanna 2013, 'Missionary Periodicals as a Genre: Models of Writing, Horizons of Expectation', In Felicity Jensz and Hanna Acke (eds.), Missions and Media: The Politics of Missionary Periodicals in the Long Nineteenth Century, Franz Steiner Verlag, Stuttgart, pp. 225-43.

‘Aitken, Very Rev. James', Register of New Zealand Presbyterian Church Ministers, Deaconesses\& Missionaries from 1840, Accessed February 22, 2016 at: http://www.archives.presbyterian.org.nz/Page146.htm

Altholz, Josef L 1989, The Religious Press in Britain, 1760-1900, Greenwood Press, Westport.

Altick, Richard D 1957, The English Common Reader: A Social History of the Mass Reading Public 1800-1900, University of Chicago Press, Chicago.

Anderson, Benedict 1991, Imagined Communities: Reflections on the Origin and Spread of Nationalism, revised edition, Verso, London, New York.

Ash, Susan 2016, Funding Philanthropy: Dr Barnardo's Metaphors, Narratives and Spectacles, Liverpool University Press, Liverpool.

Barber, Laurie 1990, ‘1901-1930: The Expanding Frontier’, In Dennis McEldowney (ed.) Presbyterians in Aotearoa 1840-1990, Presbyterian Church of New Zealand, Wellington, pp. 74-102.

Cox, Jeffrey 2008, The British Missionary Enterprise Since 1700, Routledge, New York and London.

Davin, Anna 2001, 'Waif Stories in Late Nineteenth-century England', History Workshop Journal, vol. 52 (Autumn), pp. 67-98.

Denisoff, Dennis (ed.) 2008, The Nineteenth-Century Child and Consumer Culture, Ashgate, Aldershot. 
Elleray, Michelle 2011, 'Little Builders: Coral insects, missionary culture, and the Victorian child', Victorian Literature \& Culture, vol. 39, no. 1, pp. 223-238.

Galbraith, Gretchen R 1997, Reading Lives: Reconstructing Childhood, Books and Schools in Britain, 1870-1920, Macmillan Press, Basingstoke and London.

Graham, Jeanine 2008, 'Young New Zealanders and the Great War: Exploring the Impact and Legacy of the First World War, 1914-2014', Paedagogica Historica vol. 44, no. 4, )pp. 429-444.

Graham, Jeanine 1992, My Brother and I: Glimpses of Childhood in Our Colonial Past, Hocken Library, University of Otago, Dunedin.

Greenspoon, David 2017, 'Sunday school prizes and books in early-nineteenth-century America', In Hugh Morrison and Mary Clare Martin (eds.), Creating Religious Childhoods in Anglo-World and British Colonial Contexts, 1800-1950, Routledge, London and New York, pp. 87-102.

Gubar, Marah 2009, Artful Dodgers: Reconceiving the Golden Age of Children's Literature, Oxford University Press, New York.

Haggis, Jane, and Margaret Allen 2008, 'Imperial Emotions: Affective Communities of Mission in British Protestant Women's Missionary Publications c1880-1920', Journal of Social History, vol. 41, no. 3, pp. 691-716.

Hall, Catherine 2002, Civilising Subjects: Colony and Metropole in the English Imagination, 1830-1867, University of Chicago Press, Chicago and London.

Harrison, Henrietta 2008, “"A Penny for the little Chinese”: The French Holy Childhood Association in China, 1843-1951', American Historical Review, vol. 113, pp. 72-92. Heywood, Sophie 2015, 'Missionary Children: The French Holy Childhood Association in European Context, 1843-c. 1914', European History Quarterly, vol. 45, no. 3, pp. 446-466. 
Hillel, Margot 2017, “Nearly all are supported by children”: Charitable Childhoods in LateNineteenth and Early-Twentieth Century Literature for Children in the British World', In Hugh Morrison and Mary Clare Martin (eds.), Creating Religious Childhoods in Anglo-World and British Colonial Contexts, 1800-1950, Routledge, London and New York, pp. 163-180.

Hillel, Margot 2011, “'Give us all missionary eyes and missionary hearts”: Triumphalism and missionising in late-Victorian children's literature', Mousaion, vol. 29, no. 3, pp. 179192.

Hofmeyr, Isabel 2014, 'Introduction: World Literature and the Imperial Textual Commons', English Studies in Africa, vol. 57, no. 1, pp. 1-8.

Jensz, Felicity 2012, 'Origins of Missionary Periodicals: Form and Function of Three Moravian Publications', Journal of Religious History, vol. 36, no. 2, pp. 234-255.

Jensz, Felicity and Hanna Acke (eds.) 2013, Missions and Media: The Politics of Missionary Periodicals in the Long Nineteenth Century, Franz Steiner Verlag, Stuttgart.

Johnston, Anna 2003, Missionary Writing and Empire, 1800-1860, Cambridge University Press, Cambridge.

Keen, David 1999, 'Feeding the Lambs': The Influence of Sunday Schools on the Socialization of Children in Otago and Southland, 1848-1901, doctoral thesis, University of Otago, Dunedin.

New Zealand History 2014, 'Lady Liverpool Great War Story’, viewed 4 March 2016, http://www.nzhistory.net.nz/media/video/lady-liverpool-great-war-story

Lester, Allan 2001, Imperial Networks: Creating identities in nineteenth-century South Africa and Britain, Routledge, London and New York.

McEldowney, Dennis (ed.) 1990, Presbyterians in Aotearoa 1840-1990, Presbyterian Church of New Zealand, Wellington. 
Mascarenhas, K, Gibson ME, \& Richard, M 2014, 'Little Henry’s Burdens: Colonization, Civilization, Christianity and the Child', Victorian Literature \& Culture, vol. 42, no. 3, pp. 425-438.

May, Helen 2001, 'Mapping Some Landscapes of Colonial-Global Childhood', European Early Childhood Education Research Journal, vol. 9, no. 2, pp. 5-20.

Miller, Karen Li 2012, 'The White Child's Burden: Managing the Self and Money in Nineteenth-Century Children's Missionary Periodicals', American Periodicals, vol. 22, no. 2, pp. 139-157.

Morrison, Hugh 2017, 'Service, sacrifice and responsibility: Religion and Protestant settler childhood in New Zealand and Canada, c, 1860-1940', In Hugh Morrison and Mary Clare Martin (eds.), Creating Religious Childhoods in Anglo-World and British Colonial Contexts, 1800-1950, Routledge, London and New York, pp. 241-260.

Morrison, Hugh 2016, Pushing Boundaries: New Zealand Protestants and Overseas Missions 1827-1939, Otago University Press, Dunedin.

Morrison, Hugh 2015a, “"As the sunshine dispels the darkness of the night”: Settler Protestant children's missionary magazines in New Zealand c.1840-1940', New Zealand Journal of History, vol. 20, no. 2, pp. 136-159.

Morrison, Hugh 2015b, “"I Feel That We Belong to the One Big Family”: Protestant Childhoods, Missions and Emotions in British World Settings, 1870s-1930s,' In Claire McLisky, Daniel Midena and Karen Vallgårda (eds.), Emotions and Christian Missions: Historical Perspectives, Palgrave Macmillan, Basingstoke, pp. 218-239. Morrison, Hugh 2015c, 'Settler Childhood, Protestant Christianity and Emotions in Colonial New Zealand, 1880s-1920s', In Stephanie Olsen (ed.) Childhood, Youth and Emotions in Modern History: National, Colonial and Global Perspectives, Palgrave Macmillan, Basingstoke, pp. 76-94. 
Morrison, Hugh 2013, “"Impressions which will Never Be Lost”: Missionary Periodicals for Protestant Children in Late-Nineteenth Century Canada and New Zealand', Church History, vol. 82, no. 2, pp. 388-393.

Morrison, Hugh 2012, ‘Representations of Māori in Presbyterian Children’s Missionary Literature, 190-1939’, In Hugh Morrison, Lachlan Paterson, Brett Knowles and Murray Rae (eds.), Mana Maori and Christianity, Huia Publishers, Wellington, pp. 159-178.

Murray, JS 1969, A Century of Growth: Presbyterian Overseas Mission Work 1869-1969, Presbyterian Bookroom, Christchurch.

Olsen, Stephanie 2009, 'Towards the Modern Man: Edwardian Boyhood in the Juvenile Periodical Press', In Adrienne E. Gavin and Andrew F. Humphries (eds.), Childhood in Edwardian Fiction: Worlds Enough and Time, Palgrave Macmillan, Basingstoke, pp. 159-174.

Paterson, Lachlan 2012, 'The Rise and Fall of Women Field Workers within the Presbyterian Maori Mission, 1907-1970’, In Hugh Morrison, Lachlan Paterson, Brett Knowles and Murray Rae (eds.), Mana Maori and Christianity, Huia Publishers, Wellington, pp. 179-204.

Platt, Jane 2015, Subscribing to Faith?: The Anglican Parish Magazine 1859-1929, Palgrave Macmillan, Basingstoke.

Prochaska, FK 1980, Women and Philanthropy in Nineteenth-Century England, Oxford University Press, Oxford.

Prochaska, FK 1978, 'Little Vessels: Children in the Nineteenth-Century English Missionary Movement', Journal of Imperial and Commonwealth History, vol. 6, no. 2, pp. 103118. 
Robert, Dana 2009, Christian Mission: How Christianity Became a World Religion, WileyBlackwell, Chichester.

Salesa, Damon 2009, 'New Zealand's Pacific', In Giselle Byrnes (ed.), The New Oxford History of New Zealand, Oxford University Press, Oxford and Melbourne, pp. 149172.

Schoepflin, Rennie B 2005, 'Making doctors and nurses for Jesus: medical missionary stories and American children', Church History, vol. 74, no. 3, pp. 557-590.

Stanley, Brian 1994, “'Missionary Regiments for Immanuel’s Service’: Juvenile Missionary Organizations in English Sunday Schools, 1841-1865', In Diana Woods (ed.), The Church and Childhood, Blackwell Publishers, Oxford, pp. 391-403.

Trepanier, James 2017, 'A "religion of the backwoods": Religion and the Canadian Boy Scout movement in the interwar period', In Hugh Morrison and Mary Clare Martin (eds.), Creating Religious Childhoods in Anglo-World and British Colonial Contexts, 1800-1950, Routledge, London and New York, pp. 222-240.

Troughton, Geoffrey 2017, “"Making Kiwi Christians: Children and religion in the House of Reed', In Hugh Morrison and Mary Clare Martin (eds.), Creating Religious Childhoods in Anglo-World and British Colonial Contexts, 1800-1950, Routledge, London and New York, pp. 181-198.

Vallgårda, Karen 2015, Imperial Childhoods and Christian Mission: Education and Emotions in South India and Denmark, Palgrave Macmillan, Basingstoke, 2015.

Vallgårda, Karen, Alexander, Kristine \& Olsen, Stephanie 2015, 'Emotions and the Global Politics of Childhood', In Stephanie Olsen (ed.), Childhood, Youth and Emotions in Modern History: National, Colonial and Global Perspectives, Palgrave Macmillan, Basingstoke, pp. 12-34. 
Vann, JD and VanArsdel, RT (eds.) 1995, Victorian Periodicals and Victorian Society, University of Toronto Press, Toronto \& Buffalo.

\section{Biographical Note}

Hugh Morrison is a Senior Lecturer at the University of Otago where he teaches in both initial teacher education and education studies programmes, including a course on children's and young people's history. He is also a research associate in History at the University of Waikato, New Zealand. In 2017 he is a Visiting Fellow at Magdalen College, Oxford University affiliated to the Centre for the History of Childhood. His research focuses are New Zealand mission and religious history alongside histories of childhood and religion in the British world. He is the author of Pushing Boundaries: New Zealand Protestants and overseas missions, 1827-1939 (Otago University Press, 2016) and is co-editor with Mary Clare Martin (University of Greenwich, UK) of Creating Religious Childhoods in Anglo-World and British Colonial Contexts, 1800-1950 (Routledge, 2017). He has also recently had published articles/chapters on: children's missionary literature; children, religion and emotions; and on missions and education. 